\title{
Characterization of $A A T 1$ : a Gene Involved in the Regulation of Amino Acid Transport in Saccharomyces cerevisiae
}

\author{
By JINNIE M. GARRETT \\ Department of Biology, Hamilton College, Clinton, New York 13323, USA
}

(Received 14 February 1989; revised 14 June 1989; accepted 19 June 1989)

\begin{abstract}
A new class of Saccharomyces cerevisiae mutants (aatl - amino acid transport) has been identified. These mutants are unable to grow on rich medium or on minimal medium supplemented with certain amino acids (isoleucine, methionine, phenylalanine, tyrosine or valine). This phenotype is directly linked to the presence of the leu 2 allele in these strains: aat 1 LEU2 organisms grow normally on all media tested. Leucine uptake through the leucinespecific permease is inhibited to $<35 \%$ of wild-type levels in aatl cells preincubated in nonpermissive media, and the activity of the general amino acid permease is also low in these conditions. aat $l$ cells are therefore unable to grow on rich media because they cannot take up enough leucine to supplement their auxotrophic requirement.
\end{abstract}

\section{INTRODUCTION}

The yeast Saccharomyces cerevisiae is able to utilize many nitrogenous compounds as its principal nitrogen source for growth (Large, 1986). A complex system of regulation (nitrogen catabolite repression) has evolved which allows the utilization of preferred nitrogen sources first; these are usually compounds that are readily metabolized to ammonia in the cytoplasm, e.g. glutamine (reviewed in Cooper, $1982 a$; Large, 1986). Although the phenomenon of nitrogen catabolite repression was described a long time ago (Hierholzer \& Holzer, 1963; Middlehoven, 1964), the molecular details of the mechanism are still under investigation. When a good nitrogen source is available, yeast will repress many pathways of amino acid catabolism, e.g. asparagine degradation (Dunlop et al., 1980), allantoin degradation (Bossinger et al., 1974), the activity of the catabolic NAD-linked glutamate dehydrogenase (Roon \& Even, 1973), and the uptake of amino acids into the cell by the general amino acid permease (GAP) (Horak, 1986). Nitrogen control of the amino acid permeases has been shown to involve at least three gene products: Npil and 2 (formally Mut2 and Mut4), which are involved in permease inactivation in ammonia, and Nprl (nitrogen permease reactivator protein; Vandenbol et al., 1987), which is essential for reactivation of transport activity in non-repressing media.

While it is obviously an advantage for the cell to shut down import and metabolism of poor nitrogen compounds when a more favourable one is available, it is also imperative that the cell have a mechanism to allow import of an essential nutrient. Therefore strains auxotrophic for a particular amino acid must be able to take up that amino acid when a preferred compound is being used as nitrogen source and nitrogen catabolite repression is in effect. This is accomplished by utilizing at least two different transport systems for most amino acids (Cooper, $1982 b$ ). The first, mentioned above, is the catabolic GAP transporter; this is a low-affinity, highcapacity system that is relatively non-specific and can import an amino acid which is in high concentration in the medium when needed as a nitrogen source (i.e. in the absence of nitrogen repression). There are also anabolic transport systems in which amino acids are brought in principally as precursors for macromolecule biosynthesis. These transporters are high-affinity,

Abbreviation: GAP, general amino acid permease. 
low-capacity systems that are specific for one, or a small group of amino acids and are responsible for uptake of an amino acid that cannot be synthesized de novo in the cell. These systems are not subject to nitrogen catabolite repression. Many are controlled by feedback inhibition or by transinhibition of structurally related compounds (Horak, 1986).

This dual set of transport systems allows yeast to grow on preferred nitrogen sources and also supplies required nutrients for growth. There is at least one known example where this type of regulation does not appear to work. Proline auxotrophs (pro1, pro2, pro3; Brandriss, 1979) are unable to grow on rich (YPD) medium, even when $0.1 \%$ proline is added to the medium. This phenotype has not been investigated in detail, however, as both the specific proline transport system (PUT4) and GAP are subject to nitrogen catabolite repression (Lasko \& Brandriss, 1981; Horak, 1986); a probable explanation is that proline auxotrophs are unable to take up sufficient proline for growth in rich medium.

This paper describes the isolation and characterization of a group of mutants unable to grow on rich media or on minimal media supplemented with certain amino acids. This particular mutant phenotype (aat 1 - amino $a$ cid transport) can only be observed in a strain auxotrophic for leucine and has been shown to be caused by the inhibition of leucine uptake under certain growth conditions.

\section{METHODS}

Strains and plasmids. The following strains of Saccharomyces cerevisiae were used: SEY2101 (MATa ura3-

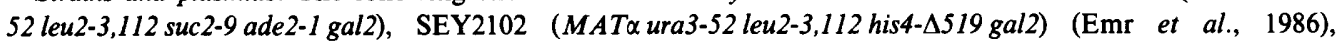
JGY1001 (as SEY2102 aat 1-1), JGY1002 (as SEY2101 aat l-2) and BC14 (MATa adel gapl-1), which was kindly supplied by B. Magasanik (Massachusetts Institute of Technology). The plasmid pZUC13 (LEU2; G. Ammerer, unpublished results) was transformed into yeast using standard methods (Sherman et al., 1986).

Media and growth conditions. Standard yeast media as described by Sherman et al. (1986) were used for all procedures. Minimal media (Wickerham, 1946) are identified as follows: MA, minimal-glucose-ammonia; MP, minimal-glucose-proline. Supplements were added at the following concentrations $\left(\mathrm{mg}^{-1}\right)$ when required: histidine 20; leucine, 30; adenine, 30; and uracil, 30. Minimal media containing a nitrogen source other than ammonia were made as follows: Bacto yeast nitrogen base without amino acids and without ammonia $\left(1 \cdot 7 \mathrm{~g}^{-1}\right)$, glucose $(2.0 \%, \mathrm{w} / \mathrm{v})$ and nitrogen source $(0.2 \%, \mathrm{w} / \mathrm{v})$; the medium was buffered to $\mathrm{pH} 5.5$ after nitrogen source addition.

Growth measurements. The doubling times of cultures in balanced growth were determined by repeated dilution of exponentially growing cultures into fresh glucose minimal medium containing $0 \cdot 2 \%$ of the specified nitrogen source and supplementary amino acids as required. The increase in optical density at $600 \mathrm{~nm}$ of cultures aerated at $30^{\circ} \mathrm{C}$ was followed for $2-4 \mathrm{~d}$ to ensure that a balanced growth rate was observed.

Mutant isolation and characterization. Cultures of SEY2102(pCBZ1) (pCBZ1 is a URA3 $2 \mu$ plasmid containing an $A T P 2-l a c Z$ gene fusion which is irrelevant to this study; Emr et al., 1986) were grown in MA medium overnight, transferred to phosphate buffer and treated with ethyl methanesulphonate (EMS, $1.5 \%$ final concn) for $30 \mathrm{~min}$. The cells were then treated with sodium thiosulphate $(5 \% \mathrm{w} / \mathrm{v})$ and dilutions were plated on minimalglycerol-ammonia plates. This treatment resulted in 50-60\% killing. Two of the resulting mutants were found to be unable to grow on YPD plates; this phenotype was not altered by curing the strain of the fusion plasmid, pCBZ1. Standard crosses were performed as described by Sherman et al. (1986).

Amino acid transport assays. Uptake of ${ }^{14} \mathrm{C}$-labelled amino acids was assayed by the method of Woodward \& Cirello (1977) in cells growing exponentially $\left(\mathrm{OD}_{600} 0.2-0.5\right)$ in the media indicated. In each case radioactive amino acid was added to a final concentration of $0.1 \mathrm{~mm}$ with a specific activity of $0.5 \mu \mathrm{Ci} \mathrm{mol}^{-1}(18.5 \mathrm{kBq}$ $\mu \mathrm{mol}^{-1}$ ) in the assay mixture. In all experiments uptake was linear over a $15 \mathrm{~min}$ assay period and the results given are the mean of at least two separate experiments. $\mathrm{L}-\left[{ }^{14} \mathrm{C}\right]$ Arginine hydrochloride $\left(150 \mathrm{mCi} \mathrm{mmol}^{-1}\right)$, $\mathrm{L}-$ $\left[{ }^{14} \mathrm{C}\right.$ glutamic acid $\left(125 \mathrm{mCi} \mathrm{mmol}^{-1}\right), \mathrm{L}-\left[{ }^{14} \mathrm{C}\right]$ leucine $\left(75 \mathrm{mCi} \mathrm{mmol}^{-1}\right)$ and L- $\left[{ }^{14} \mathrm{C}\right]$ valine $\left(125 \mathrm{mCi} \mathrm{mmol}^{-1}\right)$ were obtained from Amersham. L-[ureido $\left.{ }^{14} \mathrm{C}\right]$ Citrulline $\left(47 \mathrm{mCi} \mathrm{mmol}^{-1}\right)$ and L-[ $\left.{ }^{14} \mathrm{C}\right]$ leucine $\left(337 \mathrm{mCi} \mathrm{mmol}^{-1}\right)$ were obtained from New England Nuclear. Total protein was assayed using the method of Bradford (1976).

\section{RESULTS}

Two yeast mutants unable to grow on rich medium (YPD) were fortuitously isolated during a mutagenesis experiment. The original mutagenesis was designed to discover mitochondrial protein targeting mutants and EMS-mutagenized cells were selected on minimal-glycerolammonia medium. During subsequent stages of the isolation two mutants were identified which 


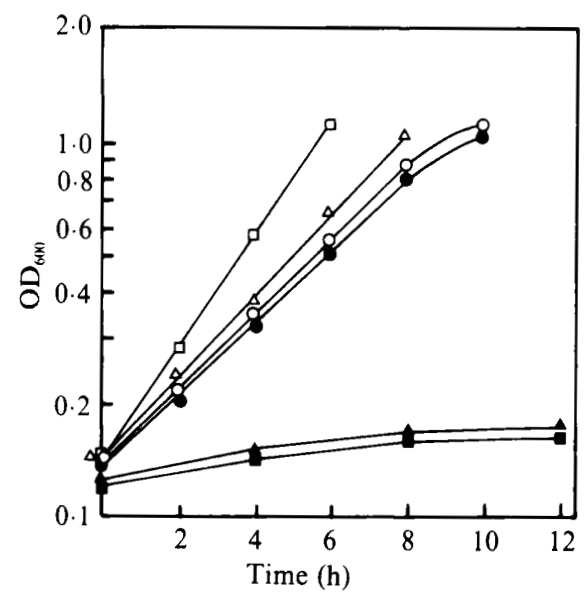

Fig. 1

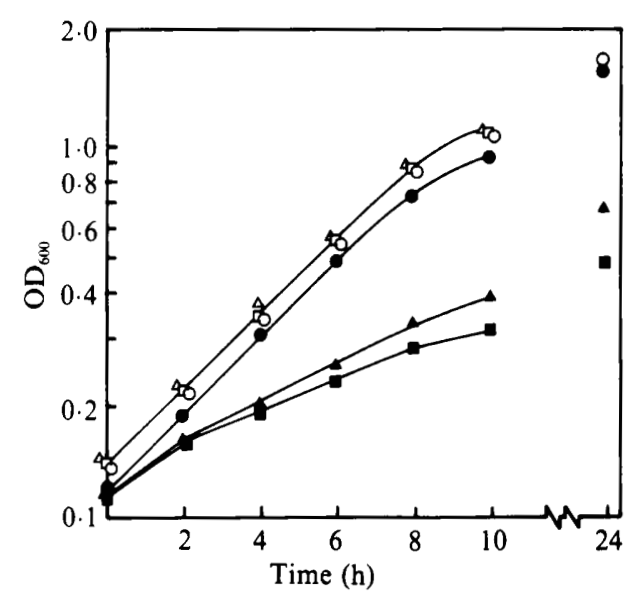

Fig. 2

Fig. 1. Growth of aat 1 yeast in minimal and rich media. Cultures of SEY2102 (MAT $\alpha$ ura3-52 leu23,112 his4- $\triangle 519 \mathrm{gal}$ ) (open symbols) and JGY1001 (as SEY2102, aat 1-1) (filled symbols) were grown in MA medium supplemented with histidine, leucine and uracil (as described in Methods) to $\mathrm{OD}_{600} 0 \cdot 5$. The cells were collected and resuspended in either the same MA $(O, O)$, YP-glucose $(\square, \square)$ or YP. glycerol $(\triangle, \Delta)$ at $\mathrm{OD}_{600} 0 \cdot 1$. The cultures were incubated at $30^{\circ} \mathrm{C}$ with aeration and the $\mathrm{OD}_{600}$ followed for $12 \mathrm{~h}$.

Fig. 2. Inhibition of growth of aatl yeast by hydrophobic amino acids. Cultures of SEY2102 (open symbols) and JGY1001 (filled symbols) were grown as described in Fig. 1. Exponentially growing cells were diluted into fresh medium $(O, O)$, or into medium to which either isoleucine $(\triangle, \triangle)$ or phenylalanine $(\square, \square)$ was added to a final concentration of $0.05 \%$. The cultures were incubated at $30^{\circ} \mathrm{C}$ with aeration and the growth rate followed for $24 \mathrm{~h}$. Methionine, tyrosine and valine had effects on the growth of aatl similar to those shown here.

failed to grow on YPD plates. When these mutants were backcrossed to the parental strain (SEY2102), tetrad analysis showed that the $\mathrm{YPD}^{-}$and mitochondrial targeting phenotypes did not co-segregate. Haploid YPD- segregants were backcrossed again and the resulting YPDstrains (JGY 1001, 1002) used in all subsequent experiments. The YPD- phenotype is completely recessive and both mutants were found to be in the same complementation group, which has been called aat 1 .

The phenotype of these mutants is quite dramatic. As shown in Fig. 1, aat1 strains grew normally at $30^{\circ} \mathrm{C}$ (and $37^{\circ} \mathrm{C}$ - data not shown) in minimal medium containing ammonia as principal nitrogen source but barely completed one doubling in rich media. Fig. 1 also illustrates that the phenotype is not growth rate dependent. The parental strain grew at approximately the same rate in MA medium as in YP-glycerol; the mutants could grow at this rate in MA medium but were unable to grow in YP-glycerol. In testing various components of rich media for growth inhibition, it was found that the growth of aat 1 in MA medium was inhibited by the addition of certain amino acids. Fig. 2 shows the effect of the addition of $0.05 \%$ isoleucine and phenylalanine on $A A T I$ and aat 1 cells growing exponentially on ammonia. The same growth inhibition was observed on addition of the other hydrophobic amino acids methionine, tyrosine and valine, either individually, or in any combination (data not shown). Other amino acids had no effect on the growth of aatl strains, except serine and threonine which, at higher concentrations $(0.2 \%)$, caused partial growth inhibition (data not shown). aatl cells that had stopped growing in these supplemented media could not be diluted and grown further in these media. This phenotype can also be clearly observed on plates; aat 1 strains form microcolonies on YPD plates or on minimal plates supplemented with any of the inhibitory amino acids. 
Table 1. Measurement of balanced growth in AAT1 and aat 1 yeast

All strains were ura3-52 leu2-3,112 his4- $\Delta 519$ gal2. The $L E U 2$ strain contained the $2 \mu$ plasmid pZUC13, which carries the LEU2 gene. The growth rate was determined by repeatedly diluting exponentially growing cells into fresh media until a balanced growth rate was obtained for $>2 \mathrm{~d}$. The media contained $1 \times$ Bacto yeast nitrogen base (without $\mathrm{NH}_{3}$ and amino acids), $2 \%(\mathrm{w} / \mathrm{v})$ glucose, $0.2 \%$ of the nitrogen source indicated, histidine $\left(20 \mathrm{mg} \mathrm{l}^{-1}\right)$, leucine $\left(30 \mathrm{mg} \mathrm{l}^{-1}\right)$ and uracil $\left(30 \mathrm{mg} \mathrm{l}^{-1}\right)$. The doubling time of all three strains on media with no nitrogen source added was $>10 \mathrm{~h}$. NG, No growth above background. No growth above background was observed in any of the strains on the following nitrogen sources: cysteine, glycine, histidine, isoleucine, lysine, methionine, phenylalanine, tyrosine and uracil. Growth of aatl leu2 was within $10 \%$ of the parental strain on the following nitrogen sources: allantoin, arginine, asparagine, citrulline, glutamate, glutamine, leucine, ornithine, proline, tryptophan and valine.

\begin{tabular}{lccc} 
Nitrogen & \multicolumn{3}{c}{ Doubling time (min) } \\
\cline { 2 - 4 } $\begin{array}{c}\text { source } \\
\text { Ammonia }\end{array}$ & 170 & aat l LEU2 & aatl leu2 \\
Adenine & 230 & 180 & 180 \\
Alanine & 225 & 220 & 320 \\
Aspartate & 190 & 225 & 320 \\
Serine & 250 & 270 & 350 \\
Threonine & 260 & 350 & 390 \\
Urea & 170 & 175 & 360 \\
YPD & 140 & 140 & NG
\end{tabular}

The aat 1 phenotype is dependent on the presence of the leu 2 allele

The two alleles of aat 1 were isolated in a leu2-3,112 ura3-52 his4-4519 gal2 background. Repeated attempts to make prototrophic strains with the aat 1 phenotype for use in single nitrogen source growth rate experiments failed to give any $\mathrm{YPD}^{-} \mathrm{LEU}^{+}$strains. As an alternative method of constructing a $\mathrm{LEU}^{+}$strain, JGY1001 was transformed with a $L E U 2$ containing plasmid, pZUC13; the resulting JGY1001(pZUC13) transformants were all YPD ${ }^{+}$ and showed none of the amino acid sensitivities of the auxotrophic mutant strain.

The ability of aat I yeast to use different compounds as principal nitrogen source was investigated using $A A T 1$ and aatl strains (both leu2-3,112 ura3-52 his4- $\triangle 519$ gal2) and aat transformed with the multicopy LEU2 plasmid pZUC13 (Table 1). While growth of the aatl leu2 strain was similar to wild-type on many nitrogen sources, including leucine, this strain grew more slowly than the parent $A A T 1$ leu2 strain on adenine, alanine, aspartate, serine, threonine and urea; these differences were not observed in the aat 1 LEU2 strain.

\section{Amino acid transport assays}

The linkage of the aat 1 growth phenotypes with the presence of the leu2 allele suggests that growth inhibition is associated with the ability of the cell to import and utilize leucine to supplement its leucine auxotrophy. This hypothesis is also suggested by the extreme sensitivity of aat 1 strains to leucine analogues: the growth of aat l leu2 strains on MA plates is completely inhibited by the addition of cycloleucine $\left(500 \mu \mathrm{g} \mathrm{ml}^{-1}\right)$, norleucine $\left(200 \mu \mathrm{g} \mathrm{ml}^{-1}\right)$ or trifluoroleucine $\left(100 \mu \mathrm{g} \mathrm{ml}^{-1}\right)$. These leucine analogues have no effect on the growth of either wild-type or aat 1 LEU2 yeast in these conditions (data not shown).

$S$. cerevisiae has been shown to contain at least two mechanisms for leucine uptake, one specific $\left(K_{\mathrm{T}}=0.05 \mathrm{mM}\right)$ and one non-specific $\left(K_{\mathrm{T}}=1.0 \mathrm{mM}, \mathrm{GAP}\right)$ (Horak, 1986). $\left[{ }^{14} \mathrm{C}\right]$ Leucine uptake was assayed in the parental strain at a range of substrate concentrations (Woodward \& Cirello, 1977), and the presence of both transport systems, with kinetics similar to those published previously, was demonstrated (data not shown). The rate of $\left[{ }^{14} \mathrm{C}\right]$ leucine uptake by the specific transporter was assayed using $100 \mu \mathrm{M}$-leucine and was found to be similar in wildtype and mutant cells growing in MP medium [SEY2102, $6.65 \mathrm{nmol} \mathrm{min}^{-1}\left(\right.$ mg protein) ${ }^{-1}$; JGY1001, $5.06 \mathrm{nmol} \mathrm{min}{ }^{-1}\left(\mathrm{mg}\right.$ protein) $\left.{ }^{-1}\right]$. The rate of leucine uptake in aatl yeast was 
Table 2. Rate of $\left[{ }^{14} \mathrm{C}\right]$ leucine uptake in yeast : effect of preincubation with other amino acids

Strains were ura3-52 leu2-3,112 his4- 4519 gal2. One hour prior to assay, the indicated amino acid was added to cells growing exponentially in MA medium, to a final concentration of $0.05 \%$ in the medium. After $1 \mathrm{~h}$ incubation, the cells were harvested, washed, and incubated in $10 \mathrm{~mm}$-potassium phthalate buffer containing $2 \%(\mathrm{w} / \mathrm{v})$ sucrose for $15 \mathrm{~min}$ at $30^{\circ} \mathrm{C}$. Then $100 \mu \mathrm{M}-\left[{ }^{14} \mathrm{C}\right]$ leucine $\left(0.5 \mu \mathrm{Ci}_{\mu \mathrm{mol}}{ }^{-1}\right)$ was added, and, at certain time intervals, samples were removed, filtered and washed with $10 \mathrm{ml}$ ice-cold water. Radioactivity on the filters was measured by liquid scintillation counting. In all cases uptake was linear for $>15 \mathrm{~min}$.

$\left[{ }^{14} \mathrm{C}\right]$ Leucine uptake

$\overbrace{A A T 1}^{\left[\mathrm{nmol} \mathrm{min}^{-1}\left(\mathrm{mg}_{\text {aat } 1}\right.\right.}$

Addition

$4.80(100)$

None

Alanine

$4 \cdot 26 \quad(89)$

$2 \cdot 20(46)$

Arginine

Glutamate

Glutamine

$3.36(70)$

$2 \cdot 14(45)$

3.74 (78)

$2 \cdot 26(47)$

$4.70(98)$

$2 \cdot 54(53)$

Histidine

$5 \cdot 16(108)$

2.02 (42)

Isoleucine

4.89 (102)

$3.28(68)$

Methionine

$4 \cdot 12(86)$

Phenylalanine

$1.40(29)$

$5 \cdot 60(117)$

$1.46(30)$

Serine

4.27 (89)

Threonine

$3.75 \quad(78)$

Valine

$4 \cdot 17$ (87)

YPD†

$2.44 \quad(51)$

$0.99(21)$

$1.50(31)$

1.48 (31)

$1.61(34)$

0.89 (19)

* The percentage of the $A A T 1$ rate in MA medium is shown in parentheses.

† Cultures were grown in MA medium and transferred to YPD for $1 \mathrm{~h}$ prior to the assay.

Table 3. GAP activity in aat 1 yeast

Strains and method were as described in Table 2 except that the cells were grown in either MA or MP medium and assayed for the uptake of $\left[{ }^{14} \mathrm{C}\right]$ citrulline. A gapl strain gave no activity $\left[<0 \cdot 1 \mathrm{nmol} \mathrm{min}{ }^{-1}\right.$ (mg protein $\left.)^{-1}\right]$ in these conditions.

$\begin{array}{lll}\begin{array}{c}\text { Nitrogen } \\ \text { source }\end{array} & \overbrace{A A T l} & \begin{array}{c}{\left[{ }^{14} \mathrm{C}\right] \text { Citrulline uptake }} \\ \text { Ammol } \text { min }^{-1}\left(\mathrm{mg} \mathrm{protein}^{-1}\right]\end{array} \\ \text { Proline } & 0.17 & 5.38 \\ & 5.32 & 6.93\end{array}$

approximately $50 \%$ of that of the wild-type in cells grown in MA medium. Preincubation of the cells in YPD medium led to a further significant inhibition of leucine uptake in the aat 1 strain (Table 2). In order to determine which amino acids were affecting leucine transport, this experiment was repeated with preincubation of MA-grown cells in the presence of individual amino acids for $1 \mathrm{~h}$ prior to assay. The data in Table 2 show that the amino acids which inhibit growth in aat 1 strains in MA medium are those which inhibit leucine uptake to less than $35 \%$ of the wild-type level.

The activity of the GAP system was assayed using $\left[{ }^{14} \mathrm{C}\right]$ citrulline, which enters the cell solely by this pathway, as substrate (Grenson et al., 1970). The results in Table 3 show that GAP activity in $A A T 1$ is regulated as expected: it is fully active on a poor nitrogen source (proline) and is repressed on ammonia. In contrast, the GAP activity of aat 1 is not repressed by ammonia but is inhibited completely by preincubation of the cells in YPD. This effect was investigated further; the rates of $\left[{ }^{14} \mathrm{C}\right]$ citrulline uptake by both strains growing exponentially in MP medium after preincubation with individual amino acids are given in Table 4. Many of the amino acids completely inhibited GAP activity in both strains; however, certain amino acids (arginine, 
Table 4. Inhibition of GAP activity by preincubation with other amino acids

Strains and methods were as for Table 2 except that the cells were grown in MP medium prior to the $1 \mathrm{~h}$ incubation and assayed for the uptake of $\left[{ }^{14} \mathrm{C}\right]$ citrulline.

\begin{tabular}{|c|c|c|}
\hline \multirow[b]{2}{*}{ Addition } & \multicolumn{2}{|c|}{$\begin{array}{c}{\left[{ }^{14} \mathrm{C}\right] \text { Citrulline uptake }} \\
{\left[\text { nmol } \mathrm{min}^{-1}(\mathrm{mg} \text { protein })^{-1}\right]}\end{array}$} \\
\hline & $A A T I$ & aatl \\
\hline None & $5 \cdot 32$ & 6.93 \\
\hline Alanine & $<0.1$ & $<0.1$ \\
\hline Arginine & $<0.1$ & $2 \cdot 10$ \\
\hline Aspartate & 0.3 & $2 \cdot 39$ \\
\hline Glutamate & $<0.1$ & $<0.1$ \\
\hline Histidine & $<0.1$ & $<0.1$ \\
\hline Isoleucine & $<0.1$ & $<0.1$ \\
\hline Leucine & $5 \cdot 64$ & 5.89 \\
\hline Methionine & $<0.1$ & 3.02 \\
\hline Phenylalanine & 1.61 & 3.58 \\
\hline Serine & 0.15 & 1.26 \\
\hline Threonine & $<0.1$ & $0 \cdot 34$ \\
\hline Valine & $<0 \cdot 1$ & $<0.1$ \\
\hline YPD & 0.67 & $<0.1$ \\
\hline
\end{tabular}

Table 5. Uptake of other ${ }^{14} \mathrm{C}$-labelled amino acids by aat 1 yeast

Cells were grown in either MA or MP medium and assayed using $100 \mu \mathrm{M}^{-14} \mathrm{C}$-labelled amino acid substrate as described in Table 2.

\begin{tabular}{|c|c|c|c|c|c|c|c|}
\hline \multirow[b]{3}{*}{ Amino acid } & \multirow{3}{*}{ Nitrogen source } & \multicolumn{6}{|c|}{ Amino acid uptake [nmol $\min ^{-1}$ (mg protein $\left.)^{-1}\right]$} \\
\hline & & \multicolumn{2}{|c|}{ Ammonia } & \multicolumn{2}{|c|}{ Proline } & \multicolumn{2}{|c|}{ YPD* } \\
\hline & & $A A T 1$ & aat 1 & $A A T I$ & aat 1 & $A A T 1$ & aat I \\
\hline $\begin{array}{l}\text { Arginine } \\
\text { Glutamate }\end{array}$ & & $\begin{array}{l}2 \cdot 86 \\
2 \cdot 84\end{array}$ & $\begin{array}{l}5 \cdot 75 \\
3 \cdot 13\end{array}$ & $\begin{array}{l}4 \cdot 86 \\
2 \cdot 41\end{array}$ & $\begin{array}{r}10.57 \\
1.66\end{array}$ & $\begin{array}{l}1.60 \\
1.63\end{array}$ & $\begin{array}{l}2 \cdot 52 \\
1 \cdot 13\end{array}$ \\
\hline
\end{tabular}

* Cell* Cells grown in MA were transferred to YPD medium for $1 \mathrm{~h}$ prior to assay.

aspartate, methionine, phenylalanine, serine) that inhibited GAP in $A A T I$ had little effect on citrulline uptake in aat 1 yeast.

The inhibition of both leucine-specific transport and GAP activity in aat 1 strains transferred to YPD or other non-permissive media could potentially be the result of a non-specific loss of membrane integrity. In order to test this, the rate of uptake of arginine and glutamate in $A A T I$ and aat 1 yeast was also assayed (Table 5). No significant decrease in transport of these amino acids was observed on preincubation of aatl in YPD medium.

\section{$A A T 1$ is not allelic to GAP}

JGY1001 (MAT $\alpha$ ura3-52 leu2-3,112 his4- 4519 gal2 aat 1-1) was crossed with BC14 (MATa ade1 gap 1-1) and the resulting diploid (JGY1001/G) was tested for aat 1 and gap phenotypes. JGY1001/G grew normally on both YPD and MP + D-histidine (test for gap - Rytka, 1975), showing that aatl is non-allelic to gapl.

\section{DISCUSSION}

A novel group of yeast mutants (aat 1 ) has been identified that are unable to grow on rich media or on minimal medium with certain amino acid supplements (Figs 1 and 2). This growth phenotype has been shown to be directly linked to the presence of the leu2 allele; aat 1 LEU2 yeast grow normally in all conditions investigated (Table 1). Similar types of growth inhibition 
have been observed in other studies on amino acid metabolism and transport. Meuris et al. (1967) isolated yeast mutants unable to grow on minimal media with individual amino acid additions. They found that this growth inhibition could be reversed by the addition of structurally related metabolites, e.g. inhibition by tyrosine of a $t y-i$ mutant could be reversed by the addition of phenylalanine and tryptophan. This phenotype can be explained by a mutation in a step of the biosynthetic pathway of aromatic amino acids that is in common to all three; the presence of excess tyrosine inhibits synthesis of phenylalanine and tryptophan by feedback inhibition. Similar mutants have been studied extensively in bacteria (Smith et al., 1962; Dalal et al., 1966) and have contributed significantly to our knowledge of biosynthetic pathways. However, aatl is clearly a different type of mutant; addition of all the inhibitory amino acids together does not reverse the effect (data not shown) and the mechanisms discussed above are clearly not appropriate to a YPD- phenotype.

One known example of a $\mathrm{YPD}^{-}$phenotype in yeast is found in proline auxotrophs (prol, pro2, pro3) that appear to be unable to take up proline for protein synthesis in rich medium because all the proline transport systems are known to be inhibited by components of YPD (Brandriss, 1979). The realization that the aat 1 growth defects are directly linked to the presence of the leu2 allele came from the reversion of aat 1 to YPD ${ }^{+}$when transformed with a LEU2 plasmid. This suggests that the mutant phenotype is a result of defective leucine uptake in rich or supplemented minimal media. The strain is effectively starving for leucine, even on YPD, because it is unable to take up the amino acid from the surrounding medium. This explanation is consistent with the amino acid sensitivities of aat 1 ; previous results have shown that isoleucine and valine are competitive inhibitors of leucine uptake (Bussey \& Umbarger, 1970) or alternatively, possible substrates of the system (Ramos et al., 1980). However, there have been no previous reports of the other amino acids that confer sensitivity to aat 1 (phenylalanine, methionine, etc.) affecting leucine transport. This explanation is also consistent with the sensitivity of aatl leu2 yeast to the leucine analogues cycloleucine, norleucine and trifluoroleucine.

Leucine has been shown previously to be taken up by two different transport systems in $S$. cerevisiae (Horak, 1986), and our parental strain (SEY2102) showed uptake kinetics consistent with this hypothesis (data not shown). Leucine transport was assayed at low (100 $\mu \mathrm{M})$ substrate concentrations to determine the activity of the leucine-specific system only. In these assays, aat 1 cells growing on proline had nearly wild-type $(83 \%)$ leucine transport; however, leucine transport was inhibited to only $46 \%$ of wild-type in aatl yeast growing on ammonia. Preincubation of the cells with certain amino acids further inhibited leucine uptake in aat 1 cells, and it was found that the amino acids that inhibited leucine transport to $<1.7 \mathrm{nmol}$ leucine $\min ^{-1}$ (mg protein) ${ }^{-1}$ were the same amino acids that inhibited growth (Table 2 ). The effect was particularly severe when aat $l$ cells were preincubated in YPD for $1 \mathrm{~h}$ prior to the assay (Table 2). The preincubation of $A A T 1$ yeast with these amino acids or YPD had significantly less effect on leucine transport. This effect on leucine transport must be mediated through transinhibition of one, or both, of the leucine transport systems by the amino acids loaded into the cell during the preincubation period. One possible explanation is that the regulation of the leucine-specific transporter is extremely sensitive to intracellular amino acid pool size and this, in turn, affects GAP activity. Alternatively the leucine transporter could be completely defective and the observed leucine uptake in aat 1 could be solely through the GAP.

In order to distinguish between these hypotheses, the activity of GAP was determined in cells grown in various media. The results in Table 3 show that GAP is not subject to nitrogen catabolite repression in aat 1 yeast. This was surprising, as other enzymes known to be subject to nitrogen repression (NAD-linked glutamate dehydrogenase, arginase; Cooper, 1982a) were regulated normally in aat 1 strains (data not shown). This further suggests that the leucine uptake observed in aatl could be due to GAP activity in both MA and MP media. However, $\left[{ }^{14} \mathrm{C}\right]$ citrulline uptake was inhibited in both parental and mutant MP-grown yeast by preincubation with many alternative nitrogen sources (Table 4). This shows that leucine uptake in aat 1 cannot be explained by GAP activity; preincubation of MP-grown aat 1 cells with many amino acids (e.g. alanine, histidine, glutamate) completely inhibits GAP activity (Table 4) and 
yet significant leucine uptake is observed after incubation with these amino acids (Table 2). It is significant that GAP activity in aatl strains responds differently from the wild-type on preincubation with certain nitrogen sources (e.g. arginine and urea). This is not understood at present but could be caused by altered internal pools of certain nitrogenous compounds in the mutant strain.

The conclusion from the transport studies is that both transport systems are not regulated normally in aat 1. This is not simply a result of loss of membrane integrity and function in nonpermissive media, since the rates of arginine and glutamate uptake in aatl strains were not altered in these conditions (Table 5). The phenotype does, however, appear to be linked to the size of internal amino acid pools: this relationship is being investigated further.

Mutants (aap,apf) that pleiotropically affect amino acid transport have been isolated previously by their resistance to multiple amino acid analogues in yeast (Surdin et al., 1965; Grenson \& Hennaut, 1971). Other characteristics of aap1 mutants include: the inability to grow on proline as nitrogen source; repressed GAP activity in all media; and greatly decreased levels of specific amino acid transporters ( $2-25 \%$ of wild-type). These phenotypes contrast with those of the mutants described here, which grow normally on proline, have full GAP activity and in which only the leucine transport system has been found to be inhibited. The existence of both types of mutant is interesting because it suggests that amino acid transport systems are regulated both individually in response to specific nutrient availability and collectively to provide general nitrogen sources for growth. It has also been suggested that ammonium transport may be coregulated with the amino acid transport systems (Larimore \& Roon, 1978).

The mechanisms of control of uptake of nitrogenous compounds in yeast in response to changing environmental conditions appear to be very complex and are not yet understood. It is hoped that this novel class of mutants will provide a new approach to the investigation of these pathways. At present, spontaneous temperature-sensitive revertants of aat 1 and three other aat $\left(\mathrm{YPD}^{-}\right)$groups are under investigation. A preliminary analysis has shown that those mutants include strains with very limited nitrogen source range and a $c d c$ terminal phenotype (unpublished observations).

I thank Cindy Allanson and Jan Brady for skilled technical assistance and Marjorie Brandriss for helpful discussions during the course of these experiments. The work was supported by an Academic Research Enhancement Award (GM37441) from the National Institutes of Health.

\section{REFERENCES}

Bossinger, J., LAwther, R. P. \& COOPER, T. G. (1974). Nitrogen repression of the allantoin degradative enzymes in Saccharomyces cerevisiae. Journal of Bacteriology 118, 821-829.

BRADFORD, M. (1976). A rapid and sensitive method for the quantitation of microgram quantities of protein utilizing the principle of protein-dye binding. Analytical Biochemistry 72, 248-254.

BRANDRISS, M. C. (1979). Isolation and preliminary characterization of Saccharomyces cerevisiae proline auxotrophs. Journal of Bacteriology 138, 816-822.

BuSSEY, H. \& UMBARGER, H. E. (1970). Biosynthesis of branched-chain amino acids in yeast - a trifluoroleucine-resistant mutant with altered regulation of leucine uptake. Journal of Bacteriology 103, 286294.

COOPER, T. G. (1982a). Nitrogen metabolism in Saccharomyces cerevisiae. In The Molecular Biology of the Yeast Saccharomyces, Metabolism and Gene Expression, pp. 39-99. Edited by J. N. Strathern, E. W. Jones \& J. R. Broach. Cold Spring Harbor, NY: Cold Spring Harbor Laboratory.

COOPER, T. G. (1982b). Transport in Saccharomyces cerevisiae. In The Molecular Biology of the Yeast
Saccharomyces, Metabolism and Gene Expression, pp. 399-461. Edited by J. N. Strathern, E. W. Jones \& J. R. Broach. Cold Spring Harbor, NY: Cold Spring Harbor Laboratory.

Dalal, F. R., Gots, R. E. \& Gots, J. S. (1966). Mechanism of adenine inhibition in adenine sensitive mutants of Salmonella typhimurium. Journal of Bacteriology 91, 507-517.

Dunlop, P. C., Meyer, G. M. \& Roon, R. J. (1980). Nitrogen repression of asparaginase II in Saccharomyces cerevisiae. Journal of Bacteriology 143, 422426.

Emr, S. D., Vassarotti, A., Garrett, J., Geller, B. L., TAkeda, M. \& Douglas, M. G. (1986). The amino terminus of the yeast $F_{1}-A T P a s e$ B-subunit precursor functions as a mitochondrial import signal. Journal of Cellular Biology 102, 523-533.

Grenson, M. \& Hennaut, C. (1971). Mutation affecting activity of several distinct amino acid transport systems in Saccharomyces cerevisiae. Journal of Bacteriology 105, 477-482.

Grenson, M., Hou, C. \& Grabeel, M. (1970). Multiplicity of the amino acid permeases. Journal of Bacteriology 103, 770-777. 
Hierholzer, G. \& Holzer, H. (1963). Repression der Synthese von DPN-abhangiger Glutaminsauredehydrogenase in Saccharomyces cerevisiae durch Ammonuionionen. Biochemische Zeitschrift 339, 175-181.

HoRAK, J. (1986). Amino acid transport in eucaryotic microorganisms. Biochimica et biophysica acta 864, 223-256.

LARGE, P. J. (1986). Degradation of organic nitrogen compounds by yeasts. Yeast 2, 1-34.

LARIMORE, F. S. \& RoON, R. J. (1978). Possible sitespecific reagent for the general amino acid transport system of Saccharomyces cerevisiae. Biochemistry 17, $431-436$.

Lasko, P. F. \& Brandriss, M. C. (1981). Proline transport in Saccharomyces cerevisiae. Journal of Bacteriology 148, 241-247.

Meuris, P., LaCroute, F. \& Slonimski, P. (1967). Étude systématique de mutants inhibés par leurs propres metabolites chez la levure Saccharomyces cerevisiae. Genetics 56, 149-161.

Middlehoven, W. J. (1964). The pathway of arginine breakdown in Saccharomyces cerevisiae. Biochimica et biophysica acta 93, 650-652.

Ramos, E. H., De Bongloanni, L. C. \& Stopanni, A. O. M. (1980). Kinetics of $L-\left[{ }^{14} \mathrm{C}\right]$ leucine transport in Saccharomyces cerevisiae. Effect of energy coupling inhibitors. Biochimica et biophysica acta 599, 214-231.

Roon, R. J. \& Even, H. L. (1973). Regulation of the nicotinamide adenine dinucleotide- and nicotinamide adenine dinucleotide phosphate-dependent glutamate dehydrogenases of Saccharomyces cerevisiae. Journal of Bacteriology 116, 367-372.

RYTKA, J. (1975). Positive selection of general amino acid permease mutants in Saccharomyces cerevisiae. Journal of Bacteriology 121, 562-570.

Sherman, F., Fink, G. R. \& Hicks, J. B. (1986). Methods in Yeast Genetics. Cold Spring Harbor, NY: Cold Spring Harbor Laboratory.

Smith, L. C., Raid, J. M., Lax, S. R. \& Suive, W. (1962). The control of 3-deoxy-D-arabino-heptulosonic acid-7-phosphate synthesis by phenylalanine and tyrosine. Journal of Biological Chemistry 237, 3566-3570.

Surdin, Y., Sly, W., Sire, J., Bordes, A. M. \& DE Robichon-Szulmajster, H. (1965). Propriétés et controle génétique du système d'accumulation des acides aminés chez Saccharomyces cerevisiae. Biochimica et biophysica acta 107, 546-566.

VANDENBol, M., JauniauX, J.-C., Vissers, S. \& GRENSON, M. (1987). Isolation of the NPRI gene responsible for the reactivation of ammonia sensitive amino acid permeases in Saccharomyces cerevisiae. European Journal of Biochemistry 164, 607-612.

WICKERHAM, L. J. (1946). A critical evaluation of the nitrogen assimilation tests commonly used in the classification of yeasts. Journal of Bacteriology 52, 293-301.

Woodward, J. R. \& Cirello, V. P. (1977). Amino acid transport and metabolism in nitrogen-starved cells of Saccharomyces cerevisiae. Journal of Bacteriology 130, 714-723. 